\title{
Magnetic susceptibility for characterizing areas with different potentials for sugarcane production
}

\author{
Diego Silva Siqueira(1), José Marques Júnior ${ }^{(1)}$, Daniel De Bortoli Teixeira(2), \\ Sammy Sidney Rocha Matias ${ }^{(3)}$, Livia Arantes Camargo ${ }^{(1)}$ and Gener Tadeu Pereira ${ }^{(2)}$
}

\begin{abstract}
(1)Universidade Estadual Paulista (Unesp), Faculdade de Ciências Agrárias e Veterinárias, Departamento de Solos e Adubos, Via de Acesso Prof. Paulo Donato Castellane, s/no, CEP 14884-900 Jaboticabal, SP, Brazil. E-mail: diego_silvasiqueira@yahoo.com.br, marques@fcav.unesp.br, li_arantes@yahoo.com.br (2)Unesp, Faculdade de Ciências Agrárias e Veterinárias, Departamento de Ciências Exatas, Via de Acesso Prof. Paulo Donato Castellane, s/no, CEP 14884-900 Jaboticabal, SP, Brazil. E-mail: daniel.dbt@hotmail.com, genertp@fcav.unesp.br (3)Universidade Estadual do Piauí, Departamento de Agronomia, Campus Deputado Jesualdo Cavalcanti Barros, Avenida Joaquim Nogueira de Oliveira, s/no, Aeroporto, CEP 64980-000 Corrente, PI, Brazil. E-mail: ymmsa2001@yahoo.com.br
\end{abstract}

\begin{abstract}
The objective of this work was to evaluate the use of magnetic susceptibility for characterizing the spatial variability of soil attributes and identifying areas with different potentials for sugarcane (Saccharum spp.) production. Samples were collected at 110 points $(1$ per 7 ha) in the layers of $0.00-0.20$ and $0.20-0.40$ $\mathrm{m}$, to determine the magnetic susceptibility and physical and chemical attributes of the soil. Fiber content, sucrose polarization (POL), and sugarcane yield were determined in 33 points. The spatial variability model for magnetic susceptibility was 63 and $22 \%$ more accurate in delimiting soil potential for sugarcane production than soil physical and chemical attributes at the $0.0-0.2$ and $0.2-0.4-\mathrm{m}$ layers, respectively. The spatial variability map for magnetic susceptibility was strongly correlated with clay $(0.83$ and 0.89 , respectively, for the layers) and sand contents $(-0.84$ and -0.88$)$; moderately correlated with organic matter $(-0.25$ and $-0.35)$, sum of bases ( -0.46 and 0.37$)$, cation exchange capacity $(0.22$ and 0.47$), \mathrm{pH}(-0.52$ and 0.13$)$, and POL (0.43 and 0.53$)$; and weakly correlated with sugarcane yield ( 0.26 and 0.23$)$. Magnetic susceptibility can be used to characterize the spatial variability of soil attributes and to identify areas with different potentials for sugarcane production.
\end{abstract}

Index terms: detailed mapping, geostatistics, indirect quantification, pedometrics, scaled semivariogram, spatial correlation.

\section{Susceptibilidade magnética para a caracterização de áreas com diferentes potenciais de produção de cana-de-açúcar}

Resumo - O objetivo deste trabalho foi avaliar o uso da susceptibilidade magnética para caracterizar a variabilidade espacial dos atributos do solo e identificar áreas com diferentes potenciais de produção de cana-de-açúcar (Saccharum spp.). Foram coletadas amostras em 110 pontos (1 por cada 7 ha), nas camadas de 0,00-0,20 e 0,20-0,40 m, para determinação da suscetibilidade magnética e de atributos físicos e químicos do solo. O teor de fibra, a polarização da sacarose (POL) e a produtividade da cana-de-açúcar foram determinados em 33 pontos. O modelo de variabilidade espacial da susceptibilidade magnética foi 63 e $22 \%$ mais acurado em delimitar o potencial do solo para produção da cana-de-açúcar que os atributos físicos e químicos do solo, nas camadas de $0,00-0,20$ e de $0,20-0,40 \mathrm{~m}$ de profundidade, respectivamente. $\mathrm{O}$ mapa da variabilidade espacial da susceptibilidade magnética apresentou forte correlação com o conteúdo de argila (0,83 e 0,89 , respectivamente, para as camadas) e de areia (-0,84 e - 0,88$)$; moderada correlação com a matéria orgânica (-0,25 e -0,35), a soma de bases (-046 e 0,37), a capacidade de troca catiônica $(0,22$ e 0,47$)$, o pH $(-0,52$ e 0,13$)$ e a POL $(0,43$ e 0,53$)$; e fraca correlação com a produtividade da cana-de-açúcar $(0,26$ e 0,23$)$. A susceptibilidade magnética pode ser utilizada para caracterizar a variabilidade espacial dos atributos do solo e para identificar áreas com diferentes potenciais para produção de cana-de-açúcar.

Termos para indexação: mapeamento detalhado, geoestatística, quantificação indireta, pedometria, semivariograma escalonado, correlação espacial.

\section{Introduction}

The second survey on the 2015/2016 sugarcane (Saccharum spp.) harvest in Brazil estimated national production to be 663.11 million tons
(Acompanhamento..., 2015). The state of São Paulo, with 4.64 million hectares, is the primary sugarcane producer in the country. This shows the importance of having accurate and detailed information on soils, 
which can help to make decisions on crop management (Peluco et al., 2013).

The rapid and accurate characterization of the spatial variability of soil attributes can facilitate the development of effective, local management practices. Moreover, this information is used to develop global indexes on changes in land use (Rockström et al., 2009) and tools that enable sustainable agriculture production (Siqueira et al., 2010b; Peluco et al., 2015).

According to Legros (2006), soil mapping methods can be divided in: mesh mapping observations, which map the similarity of different pedons; free or categorical mapping, which uses concepts of soillandscape to set the locations of samples; mapping using geostatistical analysis; mapping using fuzzy logic; and mapping of the land use potential. Some researchers (McBratney et al., 2000) proposed hybrid mapping, involving different methods with geostatistics, in order to improve the quality of the spatial information maps.

However, the precision and accuracy of these procedures depend on the number of observation points (Siqueira et al., 2014), which are related to the costs of these mappings. Other factors, such as the time required to analyze soil properties and the environmental impacts caused by laboratory reagents, are also limitations to routinely perform these procedures. This has raised the need to develop alternative techniques for the indirect quantification of soil attributes (Siqueira et al., 2010a).

Some researchers have explored the possibility of representing the site-specific soil mapping of physicochemical attributesusing electrical conductivity (Weller et al., 2007). However, the concentrations of iron oxides, abundant in tropical soils, can affect soil electrical properties (Wu et al., 2008). In Brazil, incipient researches have been carried out with geophysical tools for the indirect quantification of soil attributes (Matias et al., 2014).

Soil magnetic susceptibility is another technique with great potential for mapping and for indirect quantification of soil attributes (Resende et al., 1988; Camargo et al., 2014; Matias et al., 2014). According to Marques Jr. et al. (2014), it can be used to increase the accuracy in the delimitation of areas with different variability patterns of soil properties. Magnetic susceptibility measurements were used in the earliest experiments on the qualitative characterization of soils in the state of São Paulo, Brazil (Resende et al., 1988). Recently, Siqueira et al. (2010a) used it for the quantification of physical, chemical, and mineralogical attributes of soils with low iron content, i.e., less than $4 \%$ as $\mathrm{Fe}_{2} \mathrm{O}_{3}$. Magnetic susceptibility has also been used in sugarcane plantations in Brazil to identify areas with different potentials for soil $\mathrm{CO}_{2}$ emission (Barrios et al., 2012; Leal et al., 2015) and with different capacity to endure vinasse application (Peluco et al., 2013), as well as to quantify adsorbed phosphorus (Peluco et al., 2015) and to map management units (Matias et al., 2015; Siqueira et al., 2015). However, few works focus on identifying the relationship between magnetic susceptibility and plant characteristics (Marques Jr. et al., 2014).

The objective of this work was to evaluate the use of magnetic susceptibility for characterizing the spatial variability of soil attributes and identifying areas with different potentials for sugarcane production.

\section{Materials and Methods}

The studied area (Figure 1) is located in Guariba, a municipality in the northeast of the state of São

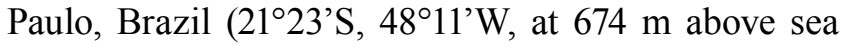
level). The climate of the region is mesothermal with dry winters, Cwa, according to Köppen. The average annual rainfall is $1,400 \mathrm{~mm}$, and the rainy period lasts from November to February. The natural vegetation consists of sub-acidophilic tropical forest plants, and the land is currently cropped with sugarcane, which is harvested mechanically without burning of crop residues. The area belongs to the geological province of the western plateau of the state of São Paulo, and its geological material is a combination of sandstones of the Bauru group of the Adamantina formation and of basalt of the Serra Geral formation (Mapa..., 1981). The soils are classified as Latossolo VermelhoAmarelo distrófico (soil taxonomy; Typic Haplustox) and Latossolo Vermelho distrófico (soil taxonomy: Typic Haplustox).

The soil map (scale 1:10,000) was prepared by Centro de Tecnologia Canavieira, the Brazilian center for sugarcane technology (Carta..., 2008). Three production environments were identified for sugarcane production (Figure 1). In order to map these production environments, edaphic factors and the potential for agricultural production should be considered (Lepsch, 1987; Maule et al., 2001). The average of soil total iron content $\left(\mathrm{Fe}_{2} \mathrm{O}_{3}\right.$, extracted by sulfuric acid) were 45.7 and $76.1 \mathrm{~g} \mathrm{~kg}^{-1}$, respectively, at the $0.00-0.20$ and $0.20-0.40-\mathrm{m}$ soil layers. 
A total of 110 points were sampled at both depths in 2007, after mechanical harvest, in an irregularly spaced grid, spanning an overall area of 770 ha. The sampling density was 1 sample per 7 ha (Figure 1). The highest sample density was observed in the northsouth direction, coinciding with the direction of greater variability in soil attributes (Camargo et al., 2014; Matias et al., 2015). The area was split into 33 plots, covering 24 ha in average. Sugarcane plants were assessed in each plot, also in 2007.

Soil samples were dried and sieved through a 2-mm mesh, prior to grain size and chemical analyses. The granulometric analysis was performed using the pipette method, using $0.1 \mathrm{~N} \mathrm{NaOH}$ as a chemical dispersant under slow mechanical stirring for 16 hours (Claessen, 1997). Exchangeable bases $(\mathrm{Ca}, \mathrm{Mg}$, and $\mathrm{K}$ ) and potential acidity $(\mathrm{H}+\mathrm{Al})$ were determined according to Raij et al. (1987). The organic matter (OM) content and $\mathrm{pH}$ were obtained as described in Claessen (1997), whereas the magnetic susceptibility was determined according to Siqueira et al. (2010a). The apparatus for magnetic susceptibility determination consists of an analytical balance, a magnet, a support for the magnet,
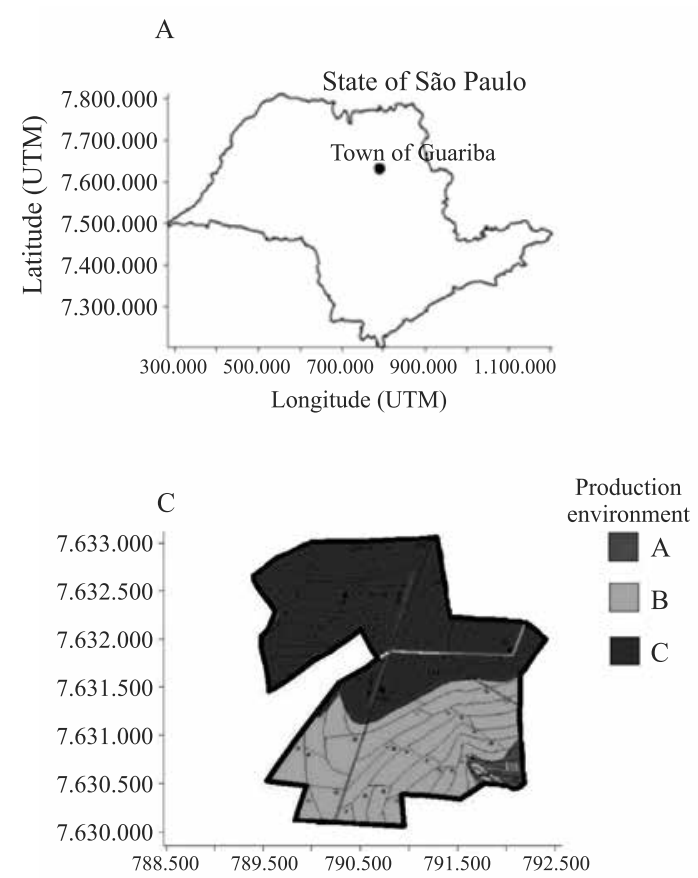

and the sample port. The interaction of the minerals showing magnetic expression with the magnet generates a weight force measured in the analytical balance. This force is converted into magnetic susceptibility weight using a standard curve. Siqueira et al. (2010a) showed that this method is feasible and that its results correlate well with sensors of magnetic susceptibility $(r=0.94)$.

Thirty three samples of sugarcane segments were collected to evaluate the following plant properties: production, consisting in cane tons per hectare $(\mathrm{CTH})$; polarization (POL), a measure of the sucrose content; and fiber content (Consecana, 2003).

Data processing was initially done with descriptive statistics, including mean, minimum, maximum, and coefficient of variation (CV). Soil attributes were analyzed in terms of their spatial dependence. The experimental semivariogram was estimated from the following expression:

$$
\widehat{\gamma}(\mathrm{h})=\frac{1}{2 \mathrm{~N}(\mathrm{~h})} \sum_{\mathrm{i}=1}^{\mathrm{N}(\mathrm{h})}\left[\left(\mathrm{z}\left(\mathrm{x}_{\mathrm{i}}\right)-\mathrm{z}\left(\mathrm{x}_{\mathrm{i}}+\mathrm{h}\right)\right]^{2}\right.
$$
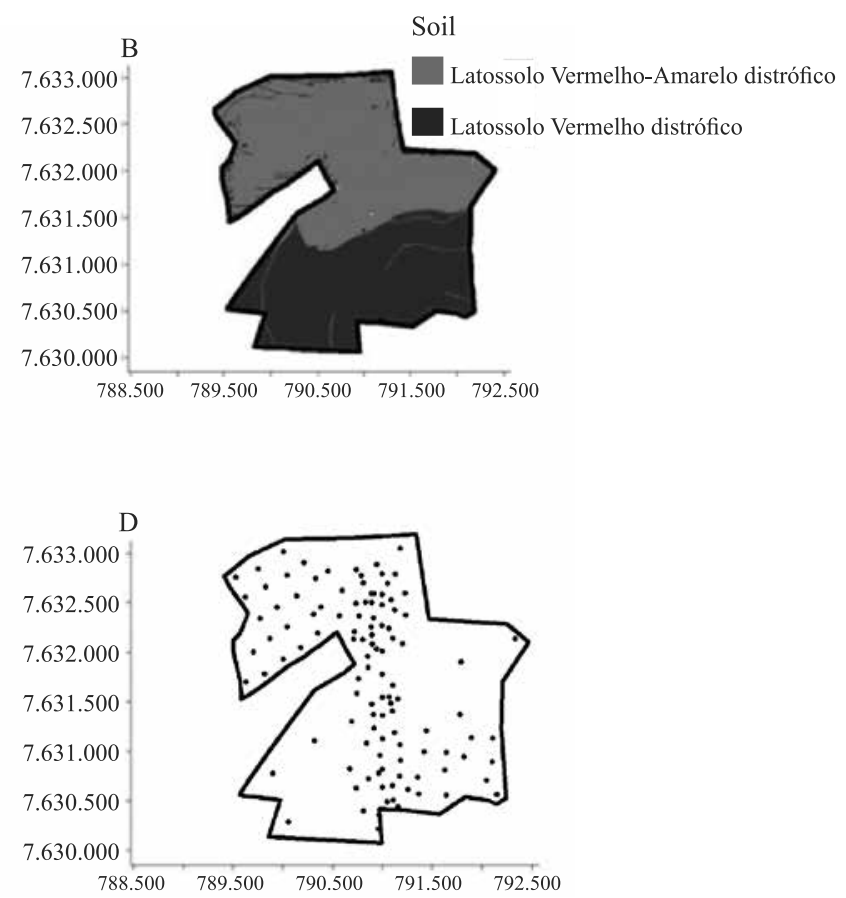

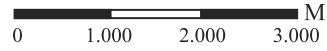

Figure 1. Location (A), soil survey map scaled at 1:10.000 (B), production environment for sugarcane (Saccharum spp.) (C), and sketch of the sampling program (D). For the production environment, A is a high productivity environment, with yield $>95 \mathrm{Mg} \mathrm{ha}^{-1}$; $\mathrm{B}$ is a high/medium productivity environment, with yield of 90-95 $\mathrm{Mg}^{-1}$; and $\mathrm{C}$ is a low productivity environment, with yield of $80-85 \mathrm{Mg} \mathrm{ha}^{-1}$. 
in which $\gamma(\mathrm{h})$ is the experimental semivariance for a separation distance $\mathrm{h} ; \mathrm{z}\left(\mathrm{x}_{\mathrm{i}}\right)$ is the attribute value at the $\mathrm{i}^{\text {th }}$ point; and $\mathrm{N}(\mathrm{h})$ is the number of pairs of points separated by distance $h$. The semivariogram model was adjusted based on cross-validations (mean and variance of residuals), external validation, and the coefficient of determination $\left(\mathrm{R}^{2}\right)$. The experimental semivariograms were modeled with 100 points. The rest of the points $(n=10)$ were used to calculate the relative root mean square error (RRMSE), for external validation. This procedure is important to eliminate feedback in model validation.

The performance of the spatial interpolation method (ordinary kriging) for soil attributes was assessed from RRMSE values, which can be considered as an accuracy index of the model. The validation methods are important to compare the models for variables with different measurement units (Li \& Heap, 2008), since they express their accuracy in terms of percentage. RRMSE was determined with the expression:

$$
\operatorname{RRMSE}=\left[(1 / \mathrm{n}) \sum_{\mathrm{i}=1}^{\mathrm{n}}\left(\left[\overline{\mathrm{z}}\left(\mathrm{x}_{\mathrm{i}}\right)-\mathrm{z}\left(\mathrm{x}_{\mathrm{i}}\right)\right] / \mathrm{z}\left(\mathrm{x}_{\mathrm{i}}\right)\right)^{2}\right]^{1 / 2}
$$

in which $\mathrm{n}$ is the number of values used in the validation; $\mathrm{z}\left(\mathrm{x}_{\mathrm{i}}\right)$ is the attribute value at the $\mathrm{i}^{\text {th }}$ point; and $\hat{z}\left(x_{i}\right)$ is the estimated attribute value at the $i^{\text {th }}$ point.

Since plant attributes were assessed at a reduced number of points (33), the ordinary kriging interpolation was impossible. Therefore, the interpolation by inverse distance weighting, a non-geostatistical method, was used instead (Kravchenko \& Bullock, 1999). The interpolation values for soil and plant attributes were estimated and formed a refined grid with a total of 893 points, regularly separated by $79 \mathrm{~m}$. Similarities in the spatial distributions of the attributes were established by spatial correlation between magnetic susceptibility maps and soil or plant attributes.

The experimental semivariograms obtained were used to construct a scaled semivariogram according to Vieira et al. (1997): $\gamma_{i}{ }^{\mathrm{sc}}(\mathrm{h})=\gamma_{\mathrm{i}}(\mathrm{h}) / \alpha_{\mathrm{i}}(\mathrm{i}=1,2 \ldots \mathrm{m})$, in which $\gamma_{i}{ }_{i}^{\text {sc }}$ is the semivariance of the scaled semivariogram at distance $h ; \gamma_{i}$ is the original semivariance at distance $h$; $\alpha$ is the scaling factor, in this case it is the variance of the attribute; and $i$ is the number of attributes.

\section{Results and Discussion}

According to the classification proposed by Warrick \& Nielsen (1980), the variability in $\mathrm{pH}$ values was low $(\mathrm{CV}=12 \%)$; in clay contents, total sand, and cation exchange capacity (CEC), it was moderate $(12 \%<\mathrm{CV}<24 \%)$; and in sum of bases (SB), OM, and magnetic susceptibility, it was high $(\mathrm{CV}>24 \%)$, at both evaluated depths (Table 1). Of these attributes, magnetic susceptibility was the one that exhibited the highest $\mathrm{CV}$. This reflects the high sensitivity of this attribute to soil processes, which change continuously across the landscape.

All attributes showed spatial dependence structure, and data in the experimental semivariograms were fitted to spherical and exponential models (Table 2). The spherical model is better adjusted for variables with abrupt transitions along the area, while the presence of an asymptotic sill in exponential models is responsible for smoother transitions in space. All studied attributes exhibited a moderate to high degree of spatial dependence (DSD), as observed by

Table 1. Descriptive statistics of soil and sugarcane (Saccharum spp.) attributes.

\begin{tabular}{|c|c|c|c|c|}
\hline Attribute $^{(1)}$ & Mean & Maximum & Minimum & $\mathrm{CV}(\%)$ \\
\hline$\overline{\text { Soil }}$ & \multicolumn{4}{|c|}{$0.0-0.2-\mathrm{m}$ depth } \\
\hline Clay $\left(\mathrm{g} \mathrm{kg}^{-1}\right)$ & 400.0 & 654.0 & 287.0 & 20.1 \\
\hline Sand $\left(\mathrm{g} \mathrm{kg}^{-1}\right)$ & 560.0 & 688.0 & 250.0 & 16.7 \\
\hline Sum of bases $\left(\mathrm{mg} \mathrm{kg}^{-1}\right)$ & 65.0 & 230.0 & 12.5 & 24.6 \\
\hline $\operatorname{CEC}\left(\mathrm{mg} \mathrm{kg}^{-1}\right)$ & 387.5 & 825.0 & 62.5 & 16.8 \\
\hline Base saturation (\%) & 60.0 & 81.1 & 18.3 & 20.0 \\
\hline $\mathrm{OM}\left(\mathrm{g} \mathrm{kg}^{-1}\right)$ & 12.3 & 30.0 & 1.8 & 79.3 \\
\hline $\mathrm{pH} \mathrm{H} \mathrm{H}_{2} \mathrm{O}$ & 5.4 & 6.4 & 4.2 & 8.5 \\
\hline \multirow[t]{2}{*}{$\operatorname{MS}\left(10^{-6} \mathrm{~m}^{3} \mathrm{~kg}^{-1}\right)$} & 6.1 & 26.0 & 0.4 & 92.0 \\
\hline & \multicolumn{4}{|c|}{$0.2-0.4-\mathrm{m}$ depth } \\
\hline Clay $\left(\mathrm{g} \mathrm{kg}^{-1}\right)$ & 449.0 & 676.0 & 330.0 & 18.2 \\
\hline Sand $\left(\mathrm{g} \mathrm{kg}^{-1}\right)$ & 513.0 & 640.0 & 234.0 & 18.7 \\
\hline Sum of bases $\left(\mathrm{mg} \mathrm{kg}^{-1}\right)$ & 290.0 & $1,100.0$ & 60.0 & 54.1 \\
\hline $\operatorname{CEC}\left(\mathrm{mg} \mathrm{kg}^{-1}\right)$ & 122.0 & 108.0 & 53.0 & 17.6 \\
\hline Base saturation (\%) & 42.0 & 88.4 & 9.8 & 43 \\
\hline $\mathrm{OM}\left(\mathrm{g} \mathrm{kg}^{-1}\right)$ & 7.6 & 18.0 & 1.4 & 64.0 \\
\hline $\mathrm{pH} \mathrm{H} \mathrm{H}_{2} \mathrm{O}$ & 4.8 & 6.3 & 3.8 & 12.0 \\
\hline $\operatorname{MS}\left(10^{-6} \mathrm{~m}^{3} \mathrm{~kg}^{-1}\right)$ & 6.3 & 27.0 & 1.4 & 88.1 \\
\hline Sugarcane & \multicolumn{4}{|c|}{ Plant (year 2007) } \\
\hline CTH $\left(\mathrm{Mg} \mathrm{ha}^{-1}\right)$ & 118.1 & 159.0 & 24.9 & 66.3 \\
\hline Sucrose polarization & 14.7 & 17.8 & 7.1 & 12.9 \\
\hline Fiber content $(\%)$ & 11.9 & 13.9 & 4.4 & 11.1 \\
\hline
\end{tabular}

${ }^{(1)} \mathrm{CEC}$, cation exchange capacity; OM, organic matter content; MS, magnetic susceptibility; and $\mathrm{CTH}$, cane tons per hectare. Soil physical and chemical attributes $n=110$, and sugarcane attributes, $n=33$. 
Cambardella et al. (1994). Clay contents, $\mathrm{pH}$ values, OM contents, and CEC values had moderate DSD at both studied depths. The magnetic susceptibility attribute showed high DSD at $0.0-0.20 \mathrm{~m}$, and moderate DSD at the higher depth. This suggests that the attribute is location-dependent and, therefore, related to the local soil formation processes. According to Maher \& Thompson (1991), magnetic minerals store natural records of soil formation factors and processes.

The spatial variability of soil attributes may be affected by both intrinsic and extrinsic factors; the latter are usually related to soil management practices (Cambardella et al., 1994). In this regard, Oxisols are assumed to exhibit relatively uniform attributes across their profiles. However, an Oxisol cropped with sugarcane for more than ten years cannot be considered uniform if its physical and chemical attributes show spatial variability, irrespectively of land use.

The range parameter of the semivariogram indicates the DSD between samples (Table 2). In practical terms, it can be used to indicate the distance between samples in the field, which ranged from 630 to $1,700 \mathrm{~m}$ in the present study. The range for magnetic susceptibility was close to that of the other soil attributes, at both sampling depths.

At both depths, the exponential models were adjusted for the scaled semivariogram of soil attributes (Figure 2), and data on magnetic susceptibility were fitted to the spherical model. Marques Jr. et al. (2014) also found magnetic susceptibility to fit a spherical model. The range parameter of the scaled semivariogram, at the $0.0-0.2$ and $0.2-0.4-\mathrm{m}$ layers, respectively, was 1,326 and $990 \mathrm{~m}$ for the soil physical and chemical attributes, and 1,450 and $1,650 \mathrm{~m}$ for magnetic susceptibility. This suggests that the spatial variability pattern of magnetic susceptibility can be used to examine the spatial variability of soil physical and chemical attributes. Matias et al. (2014) reported similar spatial variability pattern between magnetic susceptibility and soil physical and chemical attributes in the same area of study.

The nugget effect $\left(\mathrm{C}_{0}\right)$ may indicate lower error in the representation of spatial variability with the semivariogram model. The $\mathrm{C}_{0}$ parameter of the scaled semivariogram for the soil physical and chemical attributes was 0.40 and 0.45 , at the $0.0-0.2$ and $0.2-$ 0.4-m layers, respectively. For magnetic susceptibility, the $\mathrm{C}_{0}$ values were 0.15 , at the $0.0-0.2-\mathrm{m}$ depth, and 0.35 , at $0.2-0.4 \mathrm{~m}$. Accordingly, error representation of the spatial variability of magnetic susceptibility was 63 and $22 \%$ [ $\left.\left(1-\mathrm{C}_{0} \operatorname{shp} / \mathrm{C}_{0} \exp \right) 100\right]$ smaller than that of the scaled semivariogram of the soil physical and chemical attributes at the $0.00-0.20$ and $0.20-0.40-\mathrm{m}$ layers, respectively (Figure 2).

According to Cantarella et al. (2006), errors of $3-26 \%$ in the determination of soil fertility and of

Table 2. Semivariogram parameters ${ }^{(1)}$ for soil attributes.

\begin{tabular}{|c|c|c|c|c|c|c|c|c|}
\hline \multirow[t]{2}{*}{ Attribute $^{(2)}$} & \multirow[t]{2}{*}{ Model } & \multirow[t]{2}{*}{$\mathrm{C}_{0}$} & \multirow[t]{2}{*}{$\mathrm{C}_{0}+\mathrm{C}_{1}$} & \multirow[t]{2}{*}{ DSD } & \multirow[t]{2}{*}{ Range (m) } & \multirow[t]{2}{*}{$\mathrm{R}^{2}$} & \multicolumn{2}{|c|}{ Cross-validation } \\
\hline & & & & & & & Mean & Variance \\
\hline & \multicolumn{8}{|c|}{$0.0-0.2-\mathrm{m}$ depth } \\
\hline Clay & Exponential & 15 & 47 & 31.91 & 1,500 & 0.87 & 0 & 32 \\
\hline Sand & Exponential & 10 & 61 & 16.39 & 1,140 & 0.90 & 0 & 41 \\
\hline SB & Exponential & 35 & 80 & 43.75 & 855 & 0.68 & 0 & 148 \\
\hline $\mathrm{CEC}$ & Spherical & 80 & 145 & 55.17 & 1,700 & 0.71 & 0 & 174 \\
\hline OM & Spherical & 28 & 88 & 31.82 & 1,500 & 0.93 & 0 & 59 \\
\hline $\mathrm{pH}$ & Exponential & 0.08 & 0.18 & 44.44 & 1,260 & 0.6 & 0 & 0 \\
\hline \multirow[t]{2}{*}{ MS } & Spherical & $310^{-12}$ & $1.310^{-11}$ & 23.08 & 1,700 & 0.68 & 0 & 0 \\
\hline & \multicolumn{8}{|c|}{$0.2-0.4-\mathrm{m}$ depth } \\
\hline Clay & Spherical & 20 & 38 & 52.63 & 850 & 0.65 & 0 & 45 \\
\hline Sand & Exponential & 15 & 48.5 & 30.93 & 630 & 0.59 & 0 & 55 \\
\hline SB & Spherical & 45 & 185 & 24.32 & 1,000 & 0.99 & 0 & 140 \\
\hline $\mathrm{CEC}$ & Spherical & 80 & 200 & 40 & 1,200 & 0.46 & 0 & 252 \\
\hline $\mathrm{OM}$ & Spherical & 11 & 25 & 44 & 1,100 & 0.84 & 0 & 16 \\
\hline $\mathrm{pH}$ & Spherical & 0.1 & 0.34 & 29.41 & 1,200 & 0.83 & 0 & 0 \\
\hline MS & Spherical & $4.610^{-12}$ & $1.710^{-11}$ & 27.06 & 1,650 & 0.88 & 0 & 0 \\
\hline
\end{tabular}

${ }^{(1)} \mathrm{C}_{0}$, nugget effect; $\mathrm{C}_{0}+\mathrm{C}_{1}$, sill; DSD, degree of spatial dependence $\left[\mathrm{C}_{0} /\left(\mathrm{C}_{0}+\mathrm{C}_{1}\right) 100\right]$, which can be weak $(>75 \%)$, moderate $(25-75 \%)$, or strong $(\leq 25 \%)$. ${ }^{(2)} \mathrm{SB}$, sum of bases; CEC, cation exchange capacity; OM, organic matter content; and MS, magnetic susceptibility ( $\left.\mathrm{n}=100\right)$. 

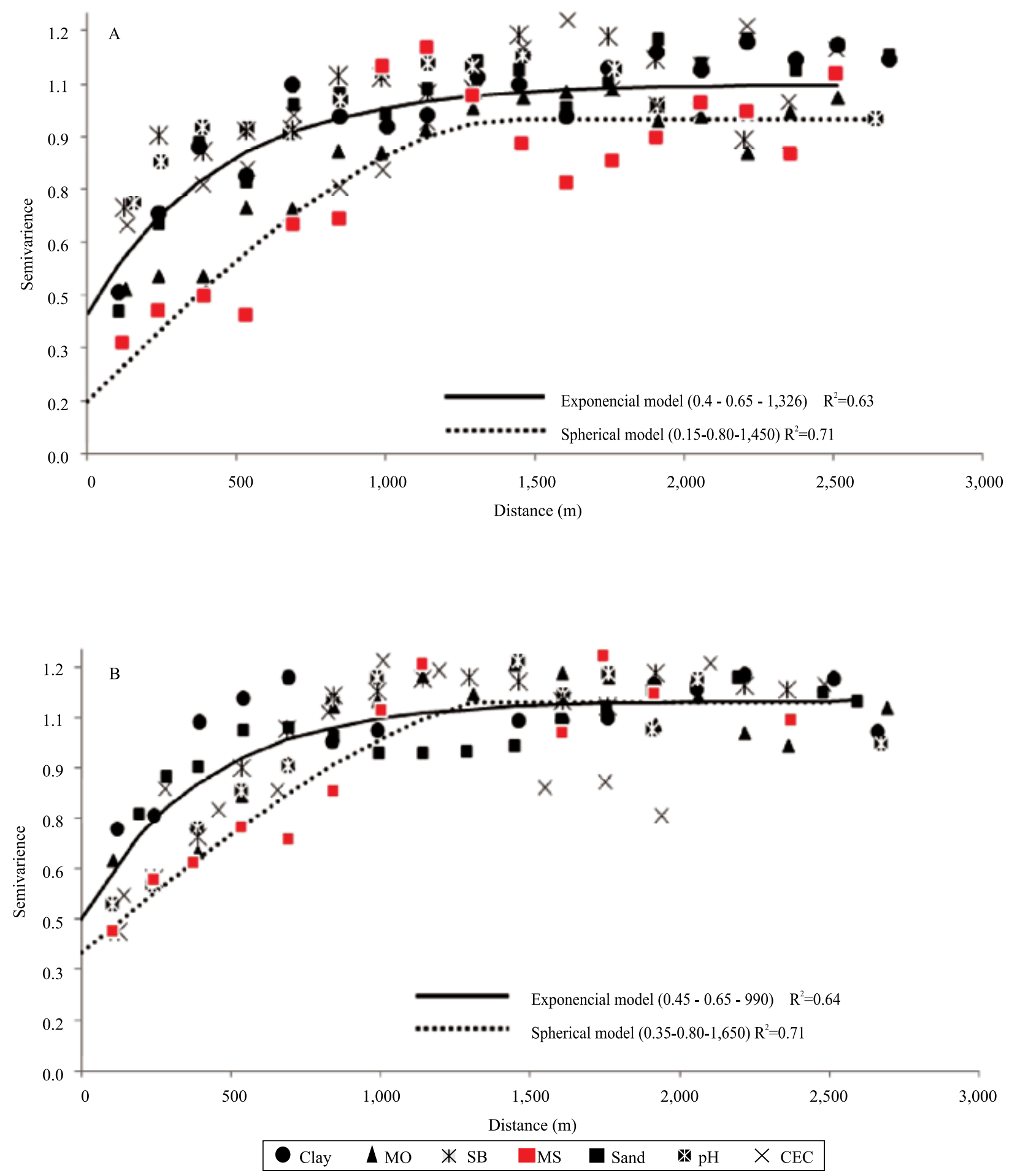

Figure 2. Scaled semivariogram for soil attributes [model (nugget effect - sill - range) $\mathrm{R}^{2}$ ]. OM, organic matter content; SB, sum of bases; MS, magnetic susceptibility; and CEC, cation exchange capacity. 
$15-32 \%$ in soil texture are common in Brazilian laboratories. Due to the high relationship between magnetic susceptibility and physical, chemical, and mineralogical attributes of the soil - identified by linear correlations (Siqueira et al., 2010a; Camargo et al., 2014; Marques Jr. et al., 2014; Siqueira et al., 2014) or by the similarity between range values in the semivariograms or by the error in the representation of the spatial variability structure (smaller $\mathrm{C}_{0}$ value) -, magnetic susceptibility can be used to improve the identification of boundaries between soil areas in the field. In addition, the lower cost in magnetic susceptibility determination allows analyzing a higher number of samples than in the conventional analyses.

With the exception of OM and CEC, few variations were observed in RRMSE at different depths in the studied attributes (Table 3). The largest uncertainties in $\mathrm{OM}$ at the $0.0-0.2-\mathrm{m}$ depth were related to the greater variability of this attribute at this depth, i.e., higher $\mathrm{C}_{0}$ value (Table 2). CEC showed lower accuracy at the $0.2-0.4-\mathrm{m}$ depth, which agrees with the greater heterogeneity of this property in the deepest layer, that is, the lower range value. The RRMSE values found for magnetic susceptibility (32\% for $0.0-0.2 \mathrm{~m}$ and $33 \%$ for $0.2-0.4 \mathrm{~m}$ ) were similar to those reported by $\mathrm{Li}$ et al. (2007), for estimating the electrical conductivity of the soil. This reinforces the idea that magnetic susceptibility might replace electrical conductivity as a measure for indirect quantification of soil attributes in areas where this technique may have limitations.

Relating the spatial distribution of magnetic susceptibility with that of other soil attributes can be of great assistance towards understanding pedogenetic processes and obtaining useful information on soil formation conditions in specific environments. This

Table 3. Relative root mean square error (RRMSE) used for external validation of soil attributes.

\begin{tabular}{lcc}
\hline Attribute $^{(1)}$ & \multicolumn{2}{c}{ RRMSE (\%) } \\
\cline { 2 - 3 } & $0.00-0.20$-m layer & $0.20-0.40$-m layer \\
\hline MS & 32 & 33 \\
Clay & 14 & 15 \\
Sand & 15 & 19 \\
pH & 9 & 9 \\
OM & 235 & 149 \\
SB & 57 & 53 \\
CEC & 19 & 46 \\
\hline
\end{tabular}

(1)MS, magnetic susceptibility; OM, organic matter content; SB, sum of bases; and CEC, cation exchange capacity $(\mathrm{n}=10)$. can help, for example, to relate the magnetic properties of soil minerals to the environment (Maher \& Thompson, 1991), which would help the proposition of accurate prediction models for other locations.

Magnetic susceptibility was especially well correlated with the soil clay content (Table 4). Matias et al. (2014) also found similarities between magnetic susceptibility and clay content maps in the same area of study, whereas Fontes et al. (2000) observed increased values of some magnetic properties with increasing clay contents. CEC exhibited positive spatial correlation with magnetic susceptibility, since both attributes are directly dependent on soil mineral composition. However, magnetic susceptibility was negatively correlated with SB, at the $0.00-0.20-\mathrm{m}$ depth. SB and base saturation (BS) are fertility attributes related to the clay fraction, but without magnetic expression. The variation of CEC in tropical soils is mainly caused by the variation of OM and iron oxide contents, such as hematite, goethite, and ferrihydrite (antiferromagnetic minerals) (Dearing, 1994). These minerals have low magnetic expression but are covariates of maghemite and magnetite, ferrimagnetic minerals, which have high magnetic susceptibility. Kaolinite and gibbsite are clay minerals and, as such, affect CEC, but they do not have magnetic expression (Dearing, 1994). The change in direction of the correlation of magnetic susceptibility with $\mathrm{BS}$ and $\mathrm{pH}$ with depth is associated with parent material. According to Camargo et al. (2014), the occurrence of mudstone intrusion in the

Table 4. Spatial correlation of the magnetic susceptibility map with soil and sugarcane (Saccharum spp.) attributes.

\begin{tabular}{|c|c|c|}
\hline \multirow[t]{2}{*}{ Attribute $^{(1)}$} & \multicolumn{2}{|c|}{ Magnetic susceptibility } \\
\hline & $0.0-0.2-\mathrm{m}$ layer & $0.2-0.4-\mathrm{m}$ layer \\
\hline & \multicolumn{2}{|c|}{ Soil } \\
\hline Clay & $0.83 * *$ & $0.89 * *$ \\
\hline Sand & $-0.84 * *$ & $-0.88 * *$ \\
\hline CEC & $0.22 * *$ & $0.47 * *$ \\
\hline SB & $-0.46^{* *}$ & $0.37 * *$ \\
\hline $\mathrm{pH}$ & $-0.52 * *$ & $0.13 * *$ \\
\hline \multirow[t]{2}{*}{$\mathrm{OM}$} & $-0.25 * *$ & $-0.35^{* *}$ \\
\hline & \multicolumn{2}{|c|}{ Plant } \\
\hline CTH in 2007 & $0.26 * *$ & $0.23 * *$ \\
\hline POL in 2007 & $0.43 * *$ & $0.53 * *$ \\
\hline Fiber content in 2007 & -0.02 & 0.08 \\
\hline
\end{tabular}

${ }^{(1)} \mathrm{CEC}$, cation exchange capacity; SB, sum of bases; OM, organic matter content; $\mathrm{CTH}$, cane tons per hectare; and POL, sucrose polarization $(\mathrm{N}=893) . * *$ Significant at $1 \%$ probability. 
sandstone material is common in the studied region and increases the concentrations of magnetic minerals with depth.

Highly weathered soils, such as the studied Oxisol, contain large amounts of variably charged $\mathrm{Al}$ and $\mathrm{Fe}$ oxides and hydroxides. Therefore, correlating CEC with magnetic susceptibility can help estimate the variation potential of charge exchange capacity at a given location. This result is interesting, since it indicates that magnetic susceptibility can be used to identify soil areas with greater or lesser nutrient uptake and sensitivity to herbicide molecules. However, this would require prior characterization of the spatial variability of magnetic susceptibility, as well as the determination of its relationship with other soil attributes.

Sugarcane attributes exhibited positive correlation with magnetic susceptibility (Table 4). Marques Jr. et al. (2014), however, reported negative correlation between POL values and magnetic susceptibility. It should be noted that this qualitative attribute was better correlated with magnetic susceptibility than it was with cane yield (CTH), a quantitative attribute. Therefore, magnetic susceptibility shows potential to be used in the identification of sites where soil conditions favor the quality of sugarcane.

The soil Latossolo Vermelho-Amarelo distrófico showed lower magnetic susceptibility than the Latossolo Vermelho distrófico. Since the studied area is in a border region between sandstone and basalt, the increase in magnetic susceptibility observed in the Latossolo Vermelho distrófico was probably due to the relation of this soil type with basalt, which is a parent material with greater magnetic susceptibility than sandstone. Fontes et al. (2000) described the variability of magnetic susceptibility for different parent materials and concluded that magnetic susceptibility is always higher in soils derived from basalt, in comparison with the ones from sedimentary rocks.

Comparing the map of production environments (Figure 1) with those of magnetic susceptibility and plant attributes (Figure 3), it was possible to perceive potential for greater yields and processing quality with increasing SM values $\left(>1210^{-6} \mathrm{~m}^{3} \mathrm{~kg}^{-1}\right)$. Therefore, magnetic susceptibility can be used to facilitate the acquisition of quantitative information from soil that can be used together with crop information for mapping purposes. However, more works are needed to clarify the relationship between these attributes.
Soil attribute

$0.0-0.2-\mathrm{m}$ depth
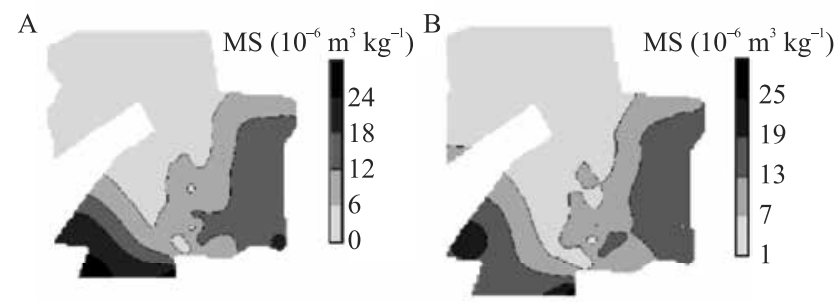

$\mathrm{C}$
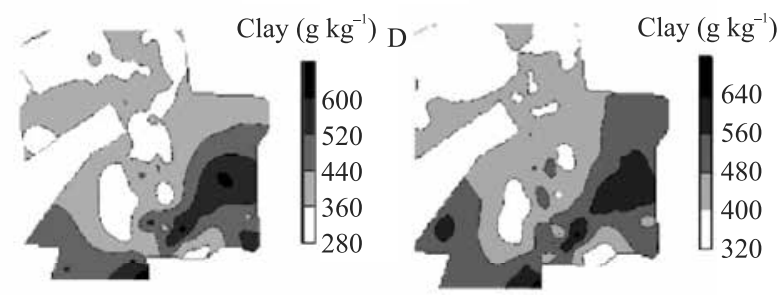

$0.2-0.4-\mathrm{m}$ depth
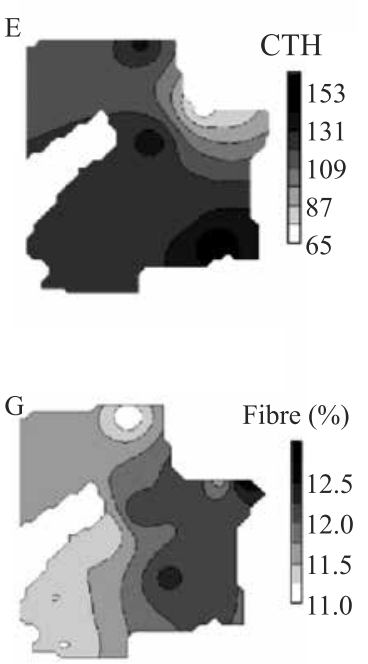

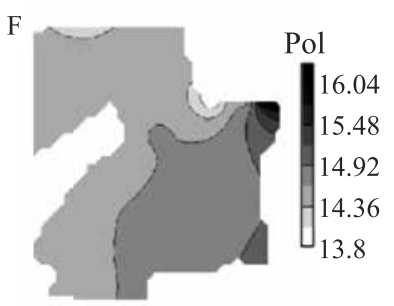

Plant attribute (year 2007)

Figure 3. Spatial distribution maps for soil attributes (A and B: MS, magnetic susceptibility; and C and D, clay) and sugarcane (Saccharum spp.) plant attributes (E, CTH, cane tons per hectare; F, Pol; and G, fibre). 


\section{Conclusion}

Magnetic susceptibility can be used to characterize the spatial variability of soil attributes and to identify areas with different potentials for sugarcane (Saccharum spp.) production.

\section{Acknowledgments}

To Fundação de Amparo à Pesquisa do Estado do São Paulo (Fapesp, Process Nos. 08/07693-3 and 09/05995-5), for scholarship and research grants; and to Conselho Nacional de Desenvolvimento Científico e Tecnológico ( $\mathrm{CNPq}$ ), for the research productivity grants for the second and sixth authors.

\section{References}

ACOMPANHAMENTO DA SAFRA BRASILEIRA [DE] CANA-DE-AÇÚCAR: safra 2015/16: segundo levantamento, Brasília, DF, v.2, n.2, ago. 2015. 33p. Available at: <http://www. conab.gov.br/OlalaCMS/uploads/arquivos/15_09_11_10_51_14_ boletim_cana_portugues_-_2o_lev_-_15-16.pdf $>$. Accessed on: Nov. 242015.

BARRIOS, M. dos R.; MARQUES JUNIOR., J.; PANOSSO, A.R.; SIQUEIRA, D.S.; LA SCALA JUNIOR, N. Magnetic susceptibility to identify landscape segments on a detailed scale in the region of Jaboticabal, São Paulo, Brazil. Revista Brasileira de Ciência do Solo, v.36, p.1073-1082, 2012. DOI: 10.1590/S010006832012000400002 .

CAMARGO, L.A.; MARQUES JÚNIOR, J.; PEREIRA, G.T.; BAHIA, A.S.R. de S. Clay mineralogy and magnetic susceptibility of Oxisols in geomorphic surfaces. Scientia Agricola, v.71, p.244-256, 2014. DOI: 10.1590/S0103-90162014000300010.

CAMBARDELLA, C.A.; MOORMAN, T.B.; NOVAK, J.M.; PARKIN, T.B.; KARLEN, D.L.; TURCO, R.F.; KONOPKA, A.E. Field-scale variability of soil properties in central Iowa soils. Soil Science Society of America Journal, v.58, p.1501-1511, 1994. DOI: $10.2136 /$ sssaj1994.03615995005800050033x.

CANTARELlA, H.; QUAGGIO, J.A.; RAIJ, B. van.; ABREU, M.F. de. Variability of soil analysis in commercial laboratories: implications for lime and fertilizer recommendations. Communications in Soil Science and Plant Analysis, v.37, p.2213-2225, 2006. DOI: 10.1080/00103620600817523.

CARTA de solos e ambientes de produção: implantação da tecnologia estará disponível às associações de fornecedores em 2008. Revista Coplana, v.3, p.24-25, 2008.

CLAESSEN, M.E.C. (Org.). Manual de métodos de análise de solo. 2.ed. rev. e atual. Rio de Janeiro: EMBRAPA-CNPS, 1997.

CONSECANA. Conselho de Produtores de Cana-de-açúcar, Açúcar e Etanol do Estado de São Paulo. Manual de instrução. 4.ed. Piracicaba: Consecana, 2003.
DEARING, J.A. Environmental magnetic susceptibility: using the Bartington MS2 system. Kenilworth: Chi Publ, 1994. 104p.

FONTES, M.P.F.; OLIVEIRA, T.S.; COSTA, L.M. da; CAMPOS, A.A.G. Magnetic separation and evaluation of magnetization of Brazilian soils from different parent materials. Geoderma, v.96, p.81-99, 2000. DOI: 10.1016/S0016-7061(00)00005-7.

KRAVCHENKO, A.; BULLOCK, D.G. A comparative study of interpretation methods for mapping soil properties. Agronomy Journal, v.91, p.393-400, 1999. DOI: 10.2134/agronj1999.00021 $962009100030007 x$.

LEAL, F.T.; FRANÇA, A.B.C.; SIQUEIRA, D.S.; TEIXEIRA, D.D.B.; MARQUES JÚNIOR, J.; LA SCALA JÚNIOR, N. Characterization of potential $\mathrm{CO}_{2}$ emissions in agricultural areas using magnetic susceptibility. Scientia Agricola, v.72, p.535-539, 2015. DOI: 10.1590/0103-9016-2014-0420.

LEGROS, J.-P. Mapping of the soil. Enfiled: Science Publishers, 2006. 411p.

LEPSCH, I.F. Influência dos fatores edáficos na produção. In: CASTRO, P.R.C.; FERREIRA, S.O.; YAMADA, T. (Coord.). Ecofisiologia da produção. Piracicaba: Associação Brasileira para Pesquisa da Potassa e do Fosfato, 1987. p.83-98.

LI, J.; HEAP, A.D. A review of spatial interpolation methods for environmental scientists. Canberra: Geoscience Australia, 2008. 154p.

LI, Y.; SHI, Z.; WU, C.; LI, H.; LI, F. Improved prediction and reduction of sampling density for soil salinity by different geostatistical methods. Agricultural Sciences in China, v.6, p.832-841, 2007. DOI: 10.1016/S1671-2927(07)60119-9.

MAHER, B.A.; THOMPSON, R. Mineral magnetic record of the Chinese loess and paleosols. Geology, v.19, p.3-6, 1991.

MAPA geomorfológico do Estado de São Paulo. São Paulo: Instituto de Pesquisas Tecnológicas do Estado de São Paulo, 1981.

MARQUES JR., J.; SIQUEIRA, D.S.; CAMARGO, L.A.; TEIXEIRA, D.D.B.; BARRÓN, V.; TORRENT, J. Magnetic susceptibility and diffuse reflectance spectroscopy to characterize the spatial variability of soil properties in a Brazilian Haplustalf. Geoderma, v.219, p.63-71, 2014. DOI: 10.1016/j. geoderma.2013.12.007.

MATIAS, S.S.R.; MARQUES JÚNIOR, J., SIQUEIRA, D.S.; PEREIRA, G.T. Outlining precision boundaries among areas with different variability standards using magnetic susceptibility and geomorphic surfaces. Engenharia Agrícola, v.34, p.695-706, 2014. DOI: $10.1590 /$ S0100-69162014000400009.

MATIAS, S.S.R.; MARQUES JÚNIOR, J.; PEREIRA, G.T.; SIQUEIRA, D.S. Ferramentas matemáticas, suscetibilidade magnética e modelos de paisagem aplicados na delimitação de áreas de manejo específico. Revista Brasileira de Ciência do Solo, v.39, p.968-980, 2015. DOI: 10.1590/01000683rbcs20140638.

MAULE, R.F.; MAZZA, J.A.; MARTHA JR., G.B. Produtividade agrícola de cultivares de cana-de-açúcar em diferentes solos e épocas de colheita. Scientia Agricola, v.58, p.295-301, 2001. DOI: $10.1590 / \mathrm{S} 0103-90162001000200012$. 
MCBRATNEY, A.B.; ODEH, I.O.A.; BISHOP, T.F.A.; DUNBAR, M.S.; SHATAR, T.M. An overview of pedometric techniques for use in soil survey. Geoderma, v.97, p.293-327, 2000. DOI: 10.1016/S0016-7061(00)00043-4.

PELUCO, R.G.; MARQUES JÚNIOR, J.; SIQUEIRA, D.S.; PEREIRA, G.T.; BARBOSA, R.S.; TEIXEIRA, D. de B.; ADAME, C.R.; CORTEZ, L.A. Suscetibilidade magnética do solo e estimação da capacidade de suporte à aplicação de vinhaça. Pesquisa Agropecuária Brasileira, v.48, p.661-672, 2013. DOI: 10.1590/S0100-204X2013000600012.

PELUCO, R.G.; MARQUES JÚNIOR, J.; SIQUEIRA, D.S.; PEREIRA, G.T.; BARBOSA, R.S.; TEIXEIRA, D. de B. Mapeamento do fósforo adsorvido por meio da cor e da suscetibilidade magnética do solo. Pesquisa Agropecuária Brasileira, v.50, p.259-266, 2015. DOI: 10.1590/S0100204X2015000300010.

RAIJ, B. van; QUAGGIO, J.A.; CANTARELLA, H.; FERREIRA, M.E.; LOOPES, A.S.; BATAGLIA, O.C. Análise química de solo para fins de fertilidade. Campinas: Fundação Cargill, 1987. $170 \mathrm{p}$.

RESENDE, M.; SANTANA, D.P.; FRANZMEIER, D.P.; COEY, J.M.D. Magnetic properties of Brazilian Oxisols. In: INTERNATIONAL SOIL CLASSIFICATION WORKSHOP, 8., 1986, Brazil. Classification, characterization and utilization of Oxisols: proceedings. Rio de Janeiro: EMBRAPA-SNLCS, 1988. p.78-108. Editors F.H. Beinroth, M.N. Camargo, and H. Eswaran.

ROCKSTRÖM, J.; STEFFEN, W.; NOONE, K.; PERSSON, A.; CHAPIN, F.S.; LAMBIN, E.F.; LENTON, T.M.; SCHEFFER, M.; FOLKE, C.; SCHELLNHUBER, H.J.; NYKVIST, B.; WIT, C.A. de; HUGHES, T.; LEEUW, S. van der; RODHE, H.; SÖRLIN, S.; SNYDER, P.K.; COSTANZA, R.; SVEDIN, U.; FALKENMARK, M.; KARLBERG, L.; CORELL, R.W.; FABRY, V.J.; HANSEN, J.; WALKER, B.; LIVERMAN, D.; RICHARDSON, K.; CRUTZEN, P.; FOLEY, J.A. A safe operating space for humanity. Nature, v.46, p.472-475, 2009. DOI: 10.1038/461472a.

SIQUEIRA, D.S.; MARQUES JR, J.;. PEREIRA, G.T.; BARBOSA, R.S.; TEIXEIRA, D.B.; PELUCO, R.G. Sampling density and proportion for the characterization of the variability of Oxisol attributes on different materials. Geoderma, v.232-234, p.172-182, 2014. DOI: 10.1016/j.geoderma.2014.04.037.

SIQUEIRA, D.S.; MARQUES JR., J.; MATIAS, S.S.R.; BARRÓN, V.; TORRENT, J.; BAFFA, O.; OLIVEIRA, L.C. Correlation of properties of Brazilian Haplustalfs with magnetic susceptibility measurements. Soil Use and Management, v.26, p.425-431, 2010a. DOI: 10.1111/j.1475-2743.2010.00294.x.

SIQUEIRA, D.S.; MARQUES JR., J.; PEREIRA, G.T. The use of landforms to predict the variability of soil and orange attributes. Geoderma, v.155, p.55-66, 2010b. DOI: 10.1016/j. geoderma.2009.11.024.

SIQUEIRA, D.S.; MARQUES JR., J.; PEREIRA, G.T.; TEIXEIRA, D.B.; VASCONCELOS, V.; CARVALHO JR., O.A.; MARTINS, E. de S. Detailed mapping unit design based on soil-landscape relation and spatial variability of magnetic susceptibility and soil color. Catena, v.135, p.149-162, 2015. DOI: 10.1016/j.catena.2015.07.010.

VIEIRA, S.R.; TILLOTSON, P.M.; BIGGAR, J.W.; NIELSEN, D.R. Scaling of semivariograms and the kriging estimation of field-measured properties. Revista Brasileira de Ciência do Solo, v.21, p.525-533, 1997. DOI: 10.1590/S0100-06831997000400001.

WARRICK, A.W.; NIELSEN, D.R. Spatial variability of soil physical properties in the field. In: HILLEL, D. Applications of soil physics. New York: Academic Press, 1980. p.319-344. DOI: 10.1016/b978-0-12-348580-9.50018-3.

WELLER, U.; ZIPPRICH, M.; SOMMER, M.; CASTELL, W.Z.; WEHRHAN, M. Mapping clay content across boundaries at the landscape scale with electromagnetic induction. Soil Science Society of America Journal, v.71, p.1740-1747, 2007. DOI: 10.2136/sssaj2006.0177.

WU, Y.; SLATER, L.; VERSTEEG, R.; LABRECQUE, D. A comparison of the low frequency electrical signatures of iron oxide versus calcite precipitation in granular zero valent iron columns. Journal of Contaminant Hydrology, v.95, p.154-167, 2008. DOI: 10.1016/j.jconhyd.2007.09.003.

Received on August 12, 2015 and accepted on February 26, 2016

Pesq. agropec. bras., Brasília, v.51, n.9, p.1349-1358, set. 2016

DOI: 10.1590/S0100-204X2016000900034 